\title{
Förderungspreis 2020 der Schweizerischen Gesellschaft für Phlebologie (SGP)
}

Die Schweizerische Gesellschaft für Phlebologie (SGP-SSP) vergibt jährlich einen Förderungspreis in Höhe von 10 000.-SFr. Dadurch sollen die wissenschaftliche Forschung, die technologische Entwicklung und die klinische Bildung auf dem Gebiet der Phlebologie im weitesten Sinne unterstützt werden. Berücksichtigt werden Arbeiten und Projekte, welche sich in einem fortgeschrittenen Stadium befinden und innerhalb 1 Jahres abgeschlossen werden können.

Bewerber richten ein ausführliches Gesuch an den Präsidenten der Schweizerischen Gesellschaft für Phlebologie, Prof. Dr. med. Jürg Hafner, Universitätsspital Zürich, CH-8091 Zürich (E-Mail: juerg.hafner@usz.ch). Das Protokoll soll per E-Mail gesendet werden (PDF-Format) und detaillierte Angaben über die Verwendung der Preissumme enthalten. Die Begutachtung des Gesuches erfolgt durch den Vorstand der Schweizerischen Gesellschaft für Phlebologie. In der Publikation soll z. B. unter „Verdankung oder Unterstützung oder Acknowledgement" der Vermerk „ausgezeichnet mit dem Förderungspreis der Schweizerischen Gesellschaft für Phlebologie“ stehen. Die Resultate sind im Rahmen einer Veranstaltung der SGP vorzustellen.

Eingabetermin: 30. Sept. 2020 Benachrichtigung des Preisträgers: Oktober 2020
Prix scientifique 2020 de la Société Suisse de Phlébologie (SSP)

La Société Suisse de Phlébologie (SSP-SGP) attribue chaque année un prix scientifique d'un montant de SFr. 10 000.-, dont le but est d'encourager la recherche scientifique, le développement technologique et la formation clinique en phlébologie. Seront pris en considération des travaux et des projets scientifiques déjà suffisamment avancés pour pouvoir être terminés dans le délai d'une année.

Les candidats au prix adresseront une demande détaillée par email (PDF) au président de la Société Suisse de Phlébologie, Prof. Dr. med. Jürg Hafner, Universitätsspital Zürich CH-8091 Zürich (E-Mail: juerg. hafner@usz.ch).

Ce rapport définira de façon détaillée, la manière dont le candidat envisage d'utiliser le montant du prix. La demande sera examinée par le comité de la Société Suisse de Phlébologie. Le travail, lors de sa publication, mentionnera sous p.ex. "remerciement ou soutien ou acknowledgement» qu'il a été «honoré du Prix de la Société Suisse de Phlébologie». Les résultats de cette recherche devront être présentés au cours d'une réunion officielle de la SSP.
Délai d'inscription: 30 sept. 2020 Avis au lauréat du prix: Octobre 2020

Scientific award 2020 of the Swiss Society of Phlebology (SSP)

Each year, the Swiss Society of Phlebology (SSP-SGP) awards a grant of CHF 10000 to a deserving scientific project. The aim is to promote scientific research and development of clinical skills in the field of phlebology. Only advanced research which can be finished with a year will be considered.

Applications should be sent as a PDF file by email to juerg.hafner@usz.ch (Prof. Dr. med. Jürg Hafner, Universitätsspital Zürich $\mathrm{CH}$-8091). The application must describe precisely how the grant would be used which will be assessed by the board of the Swiss Society of Phlebology. Publication of any results must mention (e. g. under "acknowledgements") that the project was supported by the "Award of the Swiss Society of Phlebology". The final paper should be presented at one of the next official meetings of the SSP.

Deadline: September 30, 2020 Notification of the awardee: October 2020 